\title{
CASSAVECULTUUR IN SURINAME
}

DOOR

\section{JUNKER}

Voor ongeveer twee jaren is er sprake van geweest, dat met behulp van amerikaansch kapitaal in Suriname een nieuwe cultuur in het leven zou worden geroepen. De vooruitzichten waren goed, omdat voor het product een afzetgebied werd aangeboden. In de Vereenigde Staten was behoefte aan een grondstof voor de lakfabricatie. De alcohol verkrijgbaar uit het zetmeel van de bittere cassave schijnt bijzonder goede eigenschappen te bezitten voor de samenstelling van fijne metaallakken.

Met het oog op het voornemen om uit Suriname de grondstof van den alcohol te betrekken, hield zich gedurende de tweede helft van het jaar 1927 een Amerikaansche zakenman in Suriname op. Doch eerst een jaar later werd aan het plan van eene cassavecultuur in Suriname, in Nederland meer aandacht geschonken en volgde een nader onderzoek in de Kolonie.

Suriname is echter niet gelukkig! Worden zijne kansen niet door overdreven optimisme bedorven, dan geschiedt dit zeker door ongerechtvaardigd pessimisme. In beide gevallen moet bijna altijd de hoofdoorzaak worden gezocht van onjuiste meeningen, althans omtrent de toestanden in het binnenland, in de onbekendheid met den werkelijken toestand. Zoo is het met een cassavecultuur voor Suriname, notabene de oudste Zuid-Amerikaansche cultuur, weder op eene mislukking uitgeloopen! Dat de cultuur niet tot stand is gekomen, daarin zal men moeten berusten. Ergerlijk is het echter dat tengevolgevan het onderzoek naar de mogelijkheid daarvan ingesteld, omtrent de cultuurwaarde van Suriname een onjuist en ongunstig oordeel werd geveld. Dat dit is geschied in een serieus Nederlandsch tijdschrift, de Economisch Statistische Berichten, verhoogt de beteekenis daarvan ten zeerste.

$\mathrm{Er}$ is ontegenzeggelijk veel geschetterd over de onuitputtelijke vruchtbaarheid van Suriname; hier tegenover staat echter dat de toestand in geen geval is zooals hij in hiervoren vermeld tijdschrift wordt beschreven. 
Uit Suriname werd de pessimistische uitspraak omtrent de cultuurwaarde der Kolonie niet tegengesproken, een feit dat den toestand typeert. Ten aanzien van tal van onjuiste voorstellingen echter, die voorkomen in het communiqué dat de heer Kasteleijn na het eindigen van zijn onderzoek de locale pers deed toekomen werd stelling genomen in een ingezonden stuk in de N. R. C. van 30 Mei 1929.

Beknopt samengevat komt de inhoud van de mededeelingen in de E. St. B. op het volgende neer:

1. Voor ondernemingen op grooter schaal is niet voldoende aaneengesloten cultuurland te vinden. In het algemeen is de bodem, met uitzondering van de kleigronden in het alluviale land, niet zeer vruchtbaar.

2. Wat speciaal cassave aangaat zijn de opbrengsten, 8 à 9000 $\mathrm{Kg}$. per akker, gering. In Oost-Indië wordt op eene gelijke groote oppervlakte $30.000 \mathrm{~K}$. geoogst.

3. Het is kenschetsend voor den toestand in Suriname dat voor een proefaanplant van vijftig akkers geen plantmateriaal verkregen kon worden.

Deze stellingen, vermoedelijk op in de kolonie ontvangen mededeelingen gebaseerd, moeten als onjuist worden beschouwd.

Gedurende de laatste twee jaren heeft schrijver dezes geene zich hem aanbiedende gelegenheid voorbij laten gaan om meer van de cassavencultuur te weten te komen. Oude ervaringen toetste ik opnieuw aan de werkelijke toestanden en ik nam een kleine proef met plantmateriaal. De opgedane ervaringen, in de hierna volgende beschouwingen vervat, willen slechts als een bijdrage tot de kennis van Suriname beschouwd worden.

Onderzoek op grootere schaal van land geschikt voor den landbouw heeft in het jaar 1922 ten behoeve van den heer Pyttersen plaats gehad. Toen is gebleken, dat zoowel ten westen van de Suriname-rivier als ook ten oosten daarvan in het heuvelland wel degelijk aaneengesloten stukken land, voor landbouw geschikt, worden aangetroffen.

Ten westen der rivier is het vooral het stroomgebied der Marechal-kreek, het oudste cultuurland van Suriname, dat met vrij uitgestrekte plateaux goede gelegenheden aanbiedt. Ten oosten van de Suriname-rivier strekte zich het onderzoek uit tot het stroomgebied van de Tempatie.

Het geheele onderzochte gebied is heuvelachtig. Naar het noorden dringt de savanna soms diep het heuvelland binnen, veelal in de formatie van savannabosch. Hoe uitgestrekter de plateaux zijn, 
hoe dikker de vruchtbare zandlagen die de steenverweeringen bedekken. De laatste bestaan uit graniet, ijzerdioriet, diabas en kwarts. De gemengde grond, steenen, klei en zand, is de vruchtbaarste met de uitzondering wanneer kwarts een gedeelte van het conglomeraat vormt.

De boschformatie is in den regel de indicatie van het grondtype. De kennis van de eerste stelt den onderzoeker in staat conclusies te trekken aangaande de meerdere of mindere vruchtbaarheid van den grond. Het zou te ver voeren hier verder op in te gaan: men onthoude dat deze mededeelingen zijn gebaseerd op het nagaan van honderden kostgronden, zoowel met het oog op hun ligging, als op hun productie, in de eerste plaats op die van bittere cassave.

In het onderzochte gebied werden ongeveer veertig grondmonsters genomen. Dit geschiedde, volgens de aanwijzingen van den toenmaligen landbouw-scheikundige, op deskundige wijze. De verzamelde grondmonsters werden destijds bij het landbouwproefstation ingeleverd.

Gedurende de laatste maanden van het jaar 1927 onderzocht eene Duitsche commissie het land ten westen van de Surinamerivier naar zijne geschiktheid voor den landbouw. De deskundige dier Commissie, een oud tropenplanter uit de Delischool, de heer Loag was van oordeel, dat het heuvelland aldaar groote mogelijkheden voor cacao, koffie, tabak en oliepalmen aanbood. Aan de bodem-gesteldheid werd bijzondere aandacht geschonken; op vele plaatsen werden een meter diepe gaten gedolven teneinde de samenstelling van den grond nauwkeurig te kunnen nagaan.

Het savannabosch dat met uitgestrekte plateaux tegen de steriele savanna aanleunt, had de bijzondere aandacht van den heer Loag. In de nabijheid van de Irakoekakreek werden in deze boschformatie humuslagen aangetroffen van meer dan een meter diepte.

De hiervoren vermelde onderzoekingen kunnen of hadden kunnen aantoonen dat het met de cultuurwaarde van Suriname niet zoo is gesteld als men het heeft doen voorkomen.

Bij beoordeeling van de samenstelling van bouwgrond wordt veelal slechts met de analytische uitkomst rekening gehouden. Het ontbreken van een stof, bijv. van kalk of fosfor, die volstrekt noodzakelijk voor den opbouw van een cultuurplant wordt geacht, leidt tot de conclusie dat de bodem ongeschikt is. Het aanpassingsvermogen der plant wordt buiten beschouwing gelaten.

Juist bij cassave speelt dit aanpassingsvermogen een groote rol. Een vraag met betrekking tot een ander cultuurgewas, waarop ik 
echter het antwoord schuldig blijf, dringt zich nog naar voren.

Waarom dragen de sinaasappelboomen, die de boschnegers planten, dus in het heuvelland, zoo rijkelijk en smaken de vruchten niet zoo laf als die van de boomen, die met groote zorg in de zware klei van het alluvium worden gekweekt?

Met betrekking tot de mededeelingen omtrent de opbrengst van cassave in Suriname moet worden gezegd, dat men den heer Kasteleijn in deze aangelegenheid bijzonder slecht met inlichtingen heeft gediend. Het dwingt in ieder geval bewondering af dat hij na de teleurstellende mededeelingen ontvangen te hebben nog heeft besloten tot de moeielijke reizen naar het binnenland. Een van deze eerste slechte indrukken deed op deze reizen de heer $\mathrm{K}$. nabij cassavegrond aan de Tempatie op. Men liet hem daar een verwaarloosd boschnegergrondje zien. Niet gevraagd werd hoe lang dit grondje reeds in cultuur is geweest. De grond werd ongeschikt verklaard omdat de oogenblikkelijke productie zeer gering was.

En toch behoorde het land rondom het in oogenschouw genomen kostgrondje tot het beste in Suriname voor cassavecultuur.

Het volkomen gelijke grondtype wordt in de omgeving van Bergendal aangetroffen. Aldaar heeft zich de cassave-cultuur sedert langen tijd tot eene ware volkscultuur ontwikkeld. Het product is aldaar niet alleen voedingsmiddel, de bereiding van zetmeel, van de zoogenaamde gomma, is aan de Boven Suriname tot eene kleine industrie uitgegroeid. Dit is alleen mogelijk geweest omdat de gewone kostgronden een groot surplus aan product leverden. Dat eene enkele plant in den gemengden grond (zand, steenen en klei) 20 à 30 Kilo knollen levert is geen zeldzaamheid.

Onbegrijpelijk is het, dat bij het begin van het onderzoek de literatuur niet werd geraadpleegd. Daar is in de eerste plaats het bulletin no. 23 van het Landbouw-departement in Suriname verschenen in 1910. Daarin wordt door Dr. Sack vermeld dat bittere cassave (Manihot utilissima Pohl) op vruchtbaren zandgrond $30.000 \mathrm{Kg}$. per hectare aan knollen levert.

Kappler, die cassave in het heuvelland nabij Albina verbouwde, zegt dat op niet zeer vruchtbaren grond op $25.000 \mathrm{Kg}$. per hectare kan worden gerekend en op vruchtbaren grond op meer dan het dubbele. Hij doet nog opmerken, dat enkele knollen van 4 à 5 Kg. gewicht geen zeldzaamheiden zijn. (A. Kappler, Surinam, Stuttg. 1887, 348).

Dat de aangehaalde cijfers volstrekt niet uit de lucht zijn gegrepen, kon bij herhaling gedurende de laatste twee jaren worden

West-Indische Gids XIII. 
nagegaan. Nabij de Taskreek werd een stoel cassave gerooid waarvan een enkele knol 7,1 Kg. woog. Van een andere stoel, uitgegraven aan de Simonkreek, woog een enkele knol zes Kilogram; in beide gevallen knollen tusschen de steenen uitgegraven.

Op de hooge zandgronden nabij de Jodensavanna, in de Para en elders zijn de opbrengsten geringer. Uitzondering maken gedurende jaren met gemiddelden of geringen regenval de zandklei- en lichte kleigronden. De productie, gedurende deze perioden van betrekkelijke droogte, kan op deze gronden enorm groot zijn.

Uit den aard van de zaak kunnen echter betrouwbare gemiddelde gegevens voor bepaalde eenheden oppervlakte niet worden verkregen. De creolen, boschnegers en indianen planten allen op dezelfde primitieve wijze. Van regelmaat der plant-afstanden is te eenenmale geene sprake. Ook worden door deze landbouwers bepaalde oppervlakten niet in eens afgeoogst. Van grooten invloed is verder de keuze van het bouwland. Op kostgronden in oorspronkelijk woud aangelegd zijn de opbrengsten veel geringer dan op kostgronden aangelegd in secundair bosch (Kapewerie) met een ouderdom van vier à tien jaren. Tenslotte spelen de varieteiten die uitgeplant worden geen geringe rol. Onder den dwang der noodzakelijkheid heeft de indiaansche vrouw gedurende vele eeuwen bewust geselecteerd. Als gevolg van deze selectie beschikken de primitieve landbouwers over een aantal zeer goede varieteiten van bittere cassave. Het aanpassingsvermogen der plant komt bij deze selectie goed uit. De geringe aanzet van knollen bij cassave door indianen verbouwd op hoog zandland had mijn verwondering gaande gemaakt. De eigenaar van den kostgrond zeide dat het zeer natuurlijk was dat de geplante varieteit niet kon beantwoorden en wel omdat niet de voor haar bestemde grondsoort was gekozen. De indiaan kon aantoonen dat hij gelijk had. Een andere kostgrond, aangelegd op een heuvel waarvan de grondsoort bestond uit zand, klei en ijzersteenen en die uitsluitend met de eene soort bittere cassave was beplant, stond prachtig; ofschoon de planten nauwelijksch vijf maanden oud waren, hadden ze reeds rijkelijk knollen aangezet.

Teneinde nu aan eenigszins betrouwbare gegevens voor de berekening van opbrengsten van bepaalde oppervlakten te kunnen komen werden op vele plaatsen enkele stoelen cassave uitgegraven en de knollen gewogen. Men bevond, dat de knollen van een stoel cassave gemiddeld tien kilo wegen. Met behulp van deze uitkomst is het niet moeilijk de mogelijke productie van cassave per hectare $\left(2 \frac{1}{4}\right.$ akker) te berekenen. Bij rationeele beplan- 
ting, zooals dit zeker bij de proefstations op Java plaats heeft, kunnen per hectare 8 à 9000 stoelen worden geplant. Summa summarum kan men de opbrengst aan bittere cassave in Suriname per hectare op 80 à $90.0000 \mathrm{Kg}$ stellen, wat met 33 à 40.000 $\mathrm{Kg}$. per akker overeenkomt.

Misschien zijn deze getallen niet volstrekt betrouwbaar maar in elk geval kunnen zij als vingerwijzing dienen voor de richting waarin een onderzoek dient te worden ingesteld.

De voortplanting der cassave heeft in Suriname uitsluitend door middel van stekken plaats. Nooit wordt cassave uitgezaaid. Men beweert dat zaailingen hoogstens een of twee knollen van geringe grootte aanzetten.

Naarmate de oogen aan de stammen dichter of verder van elkaar afstaan worden de stekken korter of langer gekapt. Als regel plant men op afstanden van drie à vier voet en twee stekken bij elkaar en spreekt men dan van een stoel. Op kostgronden in oorspronkelijk bosch aangelegd rijpen de knollen eerst na één en een half jaar, op Kapewerie-gronden heeft dit binnen een tijdsverloop van één jaar plaats. In het heuvelland waar de capillaire werking der gesteenten het vochtigheidsgehalte van den grond in meer of mindere mate regelt blijven de knollen tot drie jaren toe in goeden staat, op de zand-en kleigronden van het lagere land rotten deze gedurende jaren met grooten regenval reeds voor het rijpworden weg. Dit wijst erop dat de manihot een gewas van het hooge land is. Dit bewijst trouwens ook de geschiedenis van de plant. De volkenkunde leert dat de indianen, die ten huidigen dage de Guyanas bewonen, van de hoogplateaus van Brazilië en Peru afstammen. Deze hebben de cassave uit hun stamland medegebracht. De ethnologie vermeldt verder de uitvinding van het giftvrij maken van den cassave-wortel, waardoor het zetmeel voor de consumptie geschikt werd gemaakt, als een gewichtig cultuur-historisch feit.

De Creolen en boschnegers hebben de cultuur der cassave van de indianen overgenomen. Aan de Boven Suriname alleen, in het gemakkelijk te bereiken gebied stroomafwaarts van de vallen, zijn voortdurend ongeveer een honderd en vijftig hectaren in cultuur. Dit leidt onwillekeurig tot bespreking van de derde onjuiste bewering in de mededeelingen omtrent de cultuurwaarde van Suriname.

Hiervoren is vermeld dat cassave uitsluitend door middel van stekken wordt voortgeplant. In de omstreken van Bergendal heeft eene varieteit, de Koemelebo der Caraïbische vrouw, bij de 
creolen Koeletikki ${ }^{1}$ ) genoemd, alle andere cassavesoorten verdrongen. Aan de stammen dezer varieteit zitten de oogen zeer dicht bij elkaar. Van eene tienmaanden oude plant, die $24.5 \mathrm{Kg}$. aan knollen heeft opgeleverd, werden zes en dertig stoelen opnieuw geplant. Als men nu aanneemt dat op de hiervoren genoemde cultuuroppervlakte in een kleingedeelte van de Kolonie per hectare slechts 4000 stoelen worden gevonden, en dat iedere stoel voor twintig nieuwe stoelen plantmateriaal kan leveren, dan kan men berekenen dat ongeveer een tiende van de beschikbare stammetjes voldoende is om voor eene oppervlakte van vijftig akkers plantmateriaal te vinden.

Typisch moet dan ook de vraag van den schoolmeester te Bergendal worden genoemd die na het lezen der meergenoemde mededeelingen werd gesteld:

„Weten de heeren dan werkelijk niet dat hier in de omstreken zooveel cassave wordt verbouwd, of willen zij het niet weten".

Paramaribo, Maart 1931.

1) Koeletikki een woord samengesteld uit het Saramacaansch en het neger-Engelsch. Koele = rennen, loopen in dit geval uitloopen. De tikki $=$ stok loopt met vele oogen uit. De stok van deze varieteit loopt met vele stammetjes uit waardoor een breed bladerendak wordt gevormd. Het gevolg hiervan is een groote assimilatie, een der groote voordeelen dezer varieteit manihot. 